\title{
Development of Fermented Corn and Rapoko Blend Instant Porridge
}

\author{
Serere Harusekwi Julien ${ }^{1}$, Bangamusewe Blessing ${ }^{2}$, Matiringe Isabel ${ }^{1}$, Chinofunga Dorothy ${ }^{1}$ \\ ${ }^{1}$ Department of Food Science and Nutrition, Midlands State University, Gweru, Zimbabwe \\ ${ }^{2}$ World Vision, Chimanimani, Zimbabwe
}

Email address:

sererejh@msu.ac.zw (S. H. Julien), beebangah@gmail.com (B. Blessing), matiashei@msu.ac.zw (M. Isabel), chinofungad@msu.ac.zw (C. Dorothy)

\section{To cite this article:}

Serere Harusekwi Julien, Bangamusewe Blessing, Matiringe Isabel, Chinofunga Dorothy. Development of Fermented Corn and Rapoko Blend Instant Porridge. International Journal of Nutrition and Food Sciences. Vol. 5, No. 4, 2016, pp. 246-254. doi: $10.11648 /$ j.ijnfs.20160504.13

Received: April 22, 2016; Accepted: May 16, 2016; Published: June 18, 2016

\begin{abstract}
The research project's main objective was to develop a fermented corn and rapoko blend instant porridge with high nutritional profile as well as consumer acceptability so as to diversify the rapoko products on the market. Formulations were made by compositing cooked rapoko flour and fermented corn flour in the ratio $0: 100 \% ; 30: 70 \% ; 40: 60 \%$; and $60: 40 \%$ so as to come out with the optimal mixture suitable for the production of the instant porridge. The effect of rapoko flour supplementation on the proximate composition, physical properties and consumer acceptability of the blends were evaluated and the proximate analysis (protein, carbohydrate, energy, fat, fibre, moisture) was carried out on all the formulations. Consumer acceptability was also evaluated using a 9-point hedonic scale for taste, aroma, colour, appearance, texture and flavour. Physical properties such as swelling index, bulky density, reconstitution time and water holding capacity were also carried out to assess the performance of the blends in water. The results showed higher protein, carbohydrate and energy contents of the blends with increase in rapoko concentration in the mixture with $40 \%$ rapoko concentration having the highest values on the three nutrients $(11.62 ; 80.32$ and 333.52 respectively). However, the increase in rapoko caused reduction in the performance of blends in porridge such as bulky density, solubility index and the reconstitution time. Consumer preferences of the porridge decreased with increase in the rapoko concentration. The $30 \%$ rapoko blend had the best consumer acceptability but the blend with $40 \%$ rapoko had the best nutritional profile in terms of energy, carbohydrate and protein.
\end{abstract}

Keywords: Fermented Corn, Rapoko Blend Instant Porridge, Development

\section{Introduction}

Nutritional wellbeing is the key component for health and development and it contributes greatly to the human genetic potential (Saleh, 2013). The nutritional status of a community has been acknowledged to signify the development of a nation. In Zimbabwe, the food security in many households has been affected due to the past experience of persistent droughts, the downturn of the economy leading to both micronutrient and macronutrient deficiencies in the communities (FNC and MoHCW, 2010). To help solve the problem of food insecurity and malnutrition, people should consider growing of traditional food crops which are drought tolerant in order to improve dietary quality. All these are potential approaches to improve household food security and thus the community nutritional status at large.

Dietary quality affects adequate nutrition in poor communities, as malnutrition is greatly caused by inadequate amounts of food and the poor nutritional quality of the available food (Hortz and Gibson, 2007). Bioavailability and digestibility of nutrients are the two main components that affect nutrient adequacy to the body and they can be boosted by processing methods at house level which includes soaking, fermentation and germination (Hortz and Gibson, 2007). The processing methods work on improving the bioavailability of nutrients by lowering the anti-nutritional factors, such as phytates, or improving the action of enzymes on breaking down the insoluble nutrients and also to lower the viscosity of gruels through reduction of the bulk density 
of seeds (Hortz and Gibson, 2007).

Cereals are an important form of human diet as they provide starch and carbohydrate (dietary fiber), thus providing with the demands of energy and nutrient intake of humans (Verma and Patel, 2013). Diets of most Zimbabwean households are maize- based because maize is considered the staple diet. White maize (Zea mays) is a source of starch, protein, fiber and micronutrients for millions of people in sub-Saharan Africa (Onyango, 2014) though it is low in protein content $(9.4 \%)$ and micronutrients (Ng'ong'olaManani et al, 2013). Maize is an important cereal and is used together with other cereals to reduce the food insecurity problems and thus promote survival in rural areas (Afoakwa et al, 2010). The main products obtained from the white maize kernels (maize meal) are thin and thick porridges and breakfast cereals. The thin porridges are made through a combination of many processing methods like malting and fermentation in conjunction with the unit operations like dehulling, soaking, size reduction and drying so as to come out with high quality product (Afoakwa et al, 2010). Fermentation of maize constitutes an important part of the diet in many African countries as it improves the product quality by souring, leading to an improvement in its taste, flavor and texture (Mohiedeen et al, 2010). It was also found to increase shelf-life, improve palatability, nutrient digestion and nutritional value. (Mohiedeen et al, 2010).

Millets are known to have a high nutritive value as compared to other cereals such as corn, wheat and rice and their proteins are good sources of the essential amino acid methionine and are limiting in theonine and lysine and they are also good sources of photochemical and micronutrients such as calcium (Saleh et al, 2013), therefore adding value to the nutrition of populations. Rapoko, (Eleusine coracana L) also called finger millet, among the millets, contributes greatly to the human diet especially in Africa and India. It contains nearly $7 \%$ protein and like other cereals, finger millet is not rich in amino acids lysine and tryptophan (Singh and Raghuvanshi, 2012) but its protein content is better balanced as compared to all the other millets because it contains more lysine, theonine, and valine (Saleh et al, 2013). Rapoko has good amounts of tryptophan, cystine, methionine and aromatic acids, which are needed for the growth and well being of humans (Michael, n.d) and these amino acids, are deficient in most cereals rendering rapoko a special cereal among the others. Utilization of finger millet is limited due to the poor protein quality and the presence of anti-nutritional factors; phytates, phenols, tannins and enzyme inhibitors which binds to minerals thus inhibiting mineral absorption.

Breakfast cereals are the food that is obtained by soaking, swelling, roasting, toasting, grinding, rolling or flaking, shredding puffing of any cereal and which is usually eaten at breakfast (Enwere, 2005). Of all the breakfast cereals available on the market, instant porridges are the most common and they provide both health benefits and convenience (Singh et al, 2013). They are often prepared by pre-gelatinization of starches by simply precooking and drum drying to give products that readily disperse in cold water to form moderately stable suspensions (Nakorn, 2009). Instant porridges require less time and labor to prepare, they only need to be reconstituted in water before consumption, hence are suitable vehicle to provide energy and protein to rural people who are always busy in the fields and they do not find enough time to prepare decent meals for their families during the day. Studies have shown that instant porridges have longer shelf life because their water activity is very low and there is possible inactivation of lipase and lipoxygenases, the enzymes that promote lipid rancidity during heat processing (Moussa et al, 2011).

Development of the instant porridge can be an opportunity for the augmented use of rapoko in products formulations thus increased variety of rapoko products. Since fermented foods and germinated flour are both said to improve nutrient intake and decrease risk of food contamination especially when feeding young children.

\section{Method}

\subsection{Raw Materials}

Fully matured cereal grains of corn (Zea mays) variety and rapoko (E. coracana $L$ ) were used jointly to develop the fermented corn and rapoko flour. The corn and rapoko grains were purchased from a local source supplier at Kudzanai market in Gweru and were stored in a cool dry place awaiting the production of flours.

Table 1. Equipment, ingredients and reagents used in the experiment.

\begin{tabular}{ll}
\hline Equipment & Ingredients and Reagents \\
\hline Grinding machine & Sugar \\
Kjeldahl system & Salt \\
Soxhlet machine & Distilled water \\
Balance & Powdered milk \\
Oven & Corn meal \\
Measuring cylinders & Rapoko flour \\
Beakers & Boric acid \\
Test tube & Sulphuric acid and ortho-phosphoric acid \\
Centrifuge tube & Hydrogen peroxide \\
Conical flask & De-ionized water \\
Muffle furnace & Petroleum ether \\
Desiccators & Potassium sulphate \\
\hline
\end{tabular}

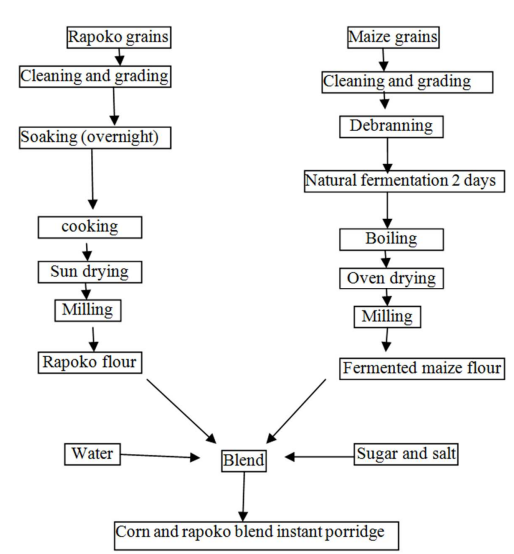

Figure 1. Flow chart showing the production process of corn and rapoko flours and the instant porridge blend. 
Table 2. Formulations of the corn and rapoko flour samples.

\begin{tabular}{lllll}
\hline \multirow{2}{*}{ Population } & \multicolumn{4}{l}{ Samples } \\
\cline { 2 - 5 } & $\mathbf{1}$ & $\mathbf{2}$ & $\mathbf{3}$ & $\mathbf{4}$ \\
\hline Rapoko flour & 0 & $300 \mathrm{~g}$ & $400 \mathrm{~g}$ & $600 \mathrm{~g}$ \\
Fermented maize flour & $1000 \mathrm{~g}$ & $700 \mathrm{~g}$ & $600 \mathrm{~g}$ & $400 \mathrm{~g}$ \\
\hline
\end{tabular}

The above, table 2 shows the formulations of the samples that were used during research. The samples were weighed using a digital scale.

Table 3. Formulation of the corn and rapoko blend instant porridge.

\begin{tabular}{lll}
\hline Ingredients & $\mathbf{1 k g}$ handy measure & $\mathbf{1 k g}$ Metric measure \\
\hline Rapoko flour & 3 cups & $400 \mathrm{~g}$ \\
Corn flour & 5 cups & $600 \mathrm{~g}$ \\
Sugar & 1 tablespoon & $10 \mathrm{~g}$ \\
Salt & 1 teaspoon & $5 \mathrm{~g}$ \\
Skimmed powdered milk & 1 tablespoon & $10 \mathrm{~g}$ \\
\hline
\end{tabular}

Adapted from (Zulu and Kambadya, 2012)

Table 3 shows the equivalent of home measure to metric scales, $300 \mathrm{~g}=2^{1 / 2}$ cups $700 \mathrm{~g}=5^{1 / 2}$ cups and $1000 \mathrm{~g}=8$ cups

\subsection{Mixing of Ingredients}

\subsubsection{Preparation of the Porridge}

Modified method adapted from (Zulu and Kambadya, 2012)

1) Mix 4 to 5 (30g-35g) heaped table spoons of the blend with $60-70 \mathrm{ml}$ of hot water or milk in a stainless steel container

2) Add a pinch of salt and a tablespoon of sugar

3) Stir the mixture until a consistency texture is reached

4) Place the mixture and container in hot water bath for 5 minutes

5) Serve whilst hot

\subsubsection{Determination of Optimum Mixing Ratios of the Flours}

The optimum mixing ratios were found by mixing the corn and rapoko flours at different concentrations so as to improve the nutritional profile and organoleptic properties of the instant blend porridge. From the formulated mixtures, the best was determined basing on the consumer acceptability and nutritional profile of the blend. The physical properties did not contribute much as all the results were almost the same in all concentration. 30:70\% formulation was found to be the best ratio with high consumer acceptance and nutrient profile.

\subsection{Protein Analysis}

This was done using Kjeldahl method as explained by Hubner and Arendt (2013) for digestion, distillation and titration of the sample to obtain the nitrogen content which was later used to calculate the protein content by the formula:

Crude protein $\%=$ total nitrogen $\%$ x 6.25

$6.25=$ Conversion factor from total nitrogen to crude protein Carl Safi et.al. (2013).

\subsection{Determination of Crude Fat}

This was done using the Soxhlet method to extract the fat from the samples as described by (Mittal, 2002).

A soxhlet extraction flask was cleaned and dried. It was then weighed. $250 \mathrm{ml}$ of petroleum ether was put in the flask. 3 grams of sample was weighed on a filter paper. The sample was then put in a thimble. Soxhlet extraction was run and after about eight cycles the petroleum ether was evaporated and the weight of fat and flask determined. To calculate the crude fat as a percent the following formula was used.

$$
\frac{\text { Weight of flask }+ \text { Sample }- \text { weight of flask alone }}{\text { Weight of sample used }} \times 100
$$

\subsection{Carbohydrate Analysis}

Total carbohydrate content of the instant porridge samples was calculated by methods of difference from the equations below:

Total carbohydrate $(\%)=100-[\%$ moisture $+\%$ crude protein $+\%$ crude fibre $+\%$ crude fat]

\section{Energy content}

To calculate the energy available in a food, multiply the number of grams of carbohydrates, protein and fats 4,4 , and $9 \mathrm{kcals}$ respectively. Then add the results together. Energy content in the corn and rapoko blend instant porridges were determined using the formula:

$$
\begin{gathered}
\text { Energy calculations }(\text { kcals })=(4 \times \text { protein }+9 \times \text { fat }+4 x \\
\text { carbohydrate }) \text { kcals. }
\end{gathered}
$$

\subsection{Moisture Content}

This was determined using the air-oven method [International Association for Cereal Chemistry (ICC 110/1, 1976)].

5 grams of sample was weighed and put in a crucible. The sample was then put in an oven at $120^{\circ} \mathrm{C}$. The sample was cooled in desiccators and reweighed until a constant weight was maintained. The percentage moisture content was determined as follows:

$\frac{\text { Weight of crucible }+ \text { sample }- \text { final weight of crucible and sample }}{5 \mathrm{~g}} \times 100$

Water holding capacity (WHC)

Modified method of Devi (2011) was used where 2.5g of the sample and $37 \mathrm{ml}$ of distilled water were mixed into a centrifuge tube. The centrifuge tube was shaken for 60 minutes and water was decanted. The weight of the residue was taken.

$$
\text { WHC }(\%)=\frac{\text { Initial sample }}{\text { Sample after soaking }- \text { initial sample }} \times 100
$$

\subsection{Bulk Density}

A $30 \mathrm{~cm}^{3}$ beaker was filled to the brim with sample, weight was taken and recorded. The beaker was emptied, cleaned and filled again with water and the water was poured into a measuring cylinder and volume was recorded (Devi 2011). 


$$
\text { Bulky density }=\frac{\text { weight of sample }(\text { grams })}{\text { Volume of water }\left(\mathrm{cm}^{3}\right)}
$$

\subsubsection{Swelling Index}

This was done as described by Devi (2012) where volume of $5 \mathrm{~g}$ of the sample was measured in a $100 \mathrm{ml}$ measuring cylinder. $50 \mathrm{ml}$ of water was then added and the mixture was swirled. The mixture was allowed to stand for an hour and the change in volume was recorded. The swelling index was then calculated by multiplying the original volume.

\subsubsection{Reconstitution Time}

A $2 \mathrm{~g}$ of each sample was dispersed in a $150 \mathrm{ml}$ graduated cylinder onto the surface of a $50 \mathrm{ml}$ of cold water. The time take for each sample to completely dissolve without stirring was recorded. This was done in triplicates and the mean value was recorded Mbaeyi-Nwaoha and Onweluzo (2013).

\subsection{Sensory Evaluation}

Sensory evaluation was done using 20 randomly selected untrained panellists from Midlands State University, Batanai Campus Students who were rating the product using the 9- point hedonic scale rating. Selection was based on interest and availability. The instant porridge was prepared by mixing $30 \mathrm{~g}$ of the corn and rapoko blend dissolved in $15 \mathrm{ml}$ boiled water for gelatinization and 9g sugar was added (Devi, 2011). Each participant was provided with 5 samples of the porridge as well as sensory evaluation score sheet designed by the researcher. The attributes which were evaluated included; texture, taste, flavour, mouth feel, colour, appearance and aroma.

\subsection{Validity and Reliability}

Reliability was tested by carrying out experiments for reliability and to see the consistency of the results. Validity was assured by the calibration of all the equipments and standardisation of the reagents used where appropriate. The utensils and instruments were also sterilised before use to avoid microbial contamination of the product during processing. All these minimised the occurrence of errors in this research.

\section{Results}

\subsection{Nutrient Analysis Results}

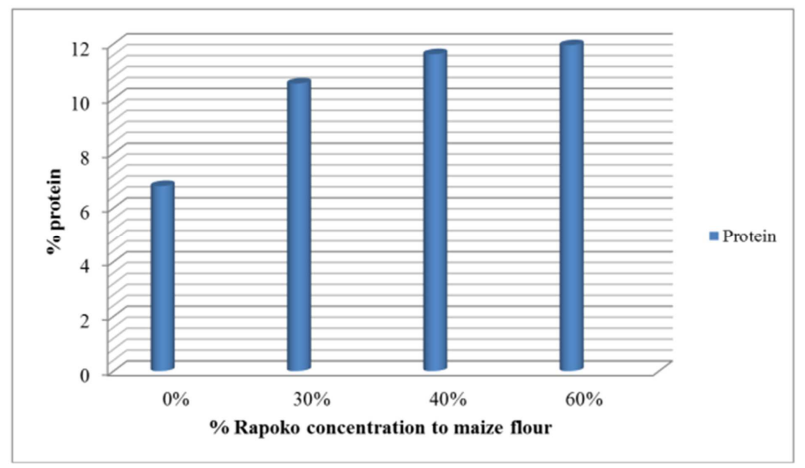

Figure 2. Protein composition of instant porridge samples.
From figure 3, the graph shows that there is an increase in protein content as we increase the concentration of rapoko in the blend from $0 \%$ to $60 \%$ concentration with a decrease in $0 \%$ concentration of rapoko.

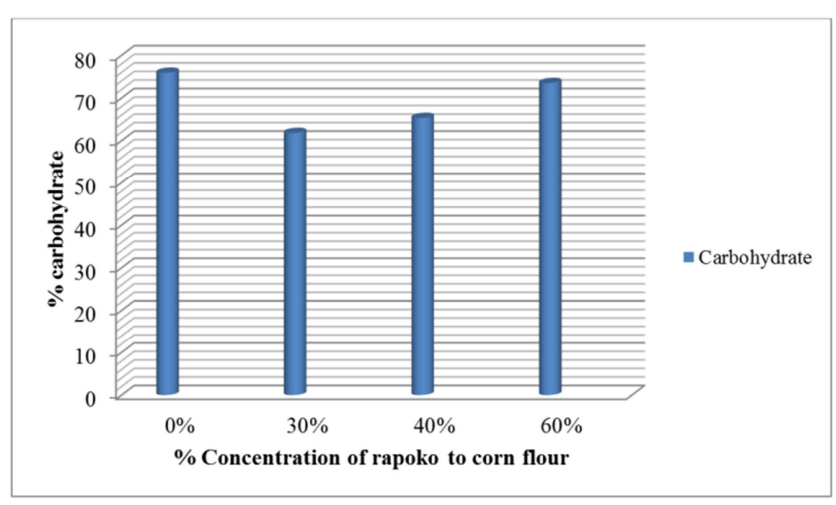

Figure 3. Carbohydrate composition of instant porridge samples.

The graph above is showing the carbohydrate content of corn and rapoko blends, the trend shows an increase in the carbohydrate content as we increase the concentration of rapoko in the porridge. In $0 \%$ rapoko the carbohydrate content is higher as compared to all the other concentrations.

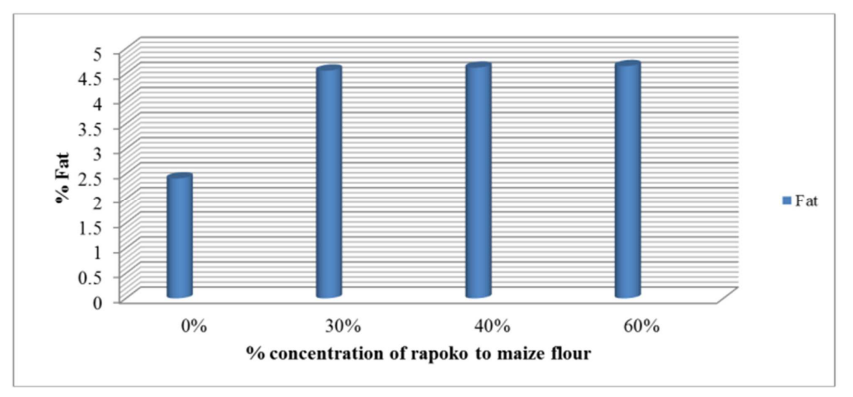

Figure 4. Fat composition of instant porridge samples.

Fig. 4 is representing the fat content of different concentrations of the corn and rapoko blends. The fat content is increasing with the increase in rapoko concentration in the blend (from $30 \%$ to $60 \%$ ), and $0 \%$ concentration have the lowest fat content.

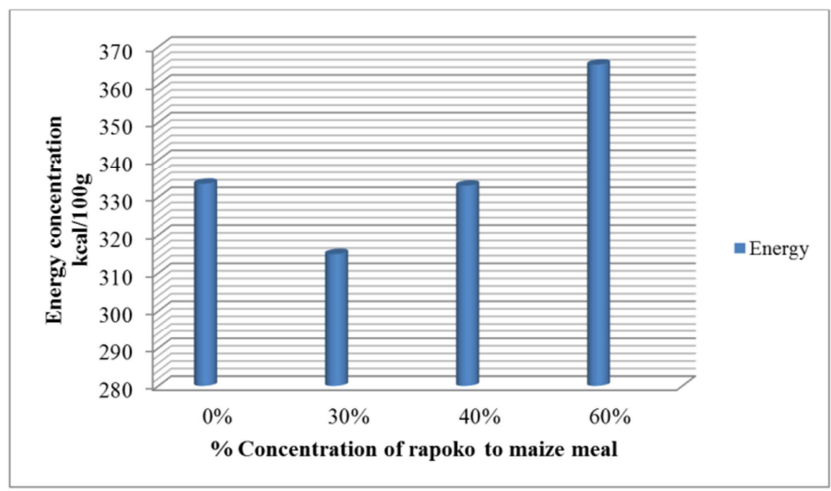

Figure 5. Energy values of the corn and rapoko instant porridge.

From the graph above, there are some variations in the energy content of the corn and rapoko blend instant 
porridges. $60 \%$ rapoko has the highest energy value as compared to the other concentrations and this is followed by $0 \%$ and $40 \%$ rapoko concentration having the lowest.

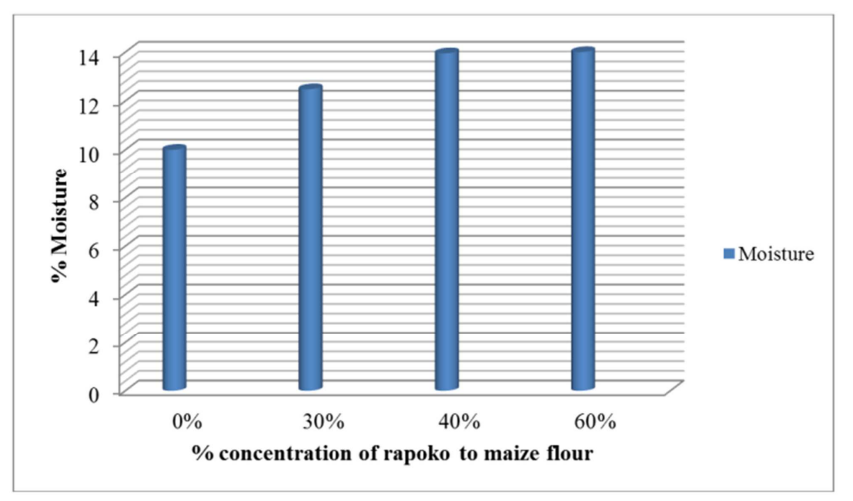

Figure 6. Moisture content of the instant porridges.

From the graph above, it is shown that moisture content increases with increase in rapoko concentration in the blend.

\subsection{Physical Properties Results}

Table 4. Showing the physical properties of corn and rapoko instant blends.

\begin{tabular}{llllll}
\hline $\begin{array}{l}\text { Water } \\
\text { holding } \\
\text { capacity }\end{array}$ & $\begin{array}{l}\text { Bulky } \\
\text { density } \\
\text { g/cm }\end{array}$ & $\begin{array}{l}\text { Reconstitutio } \\
\text { n time in min. }\end{array}$ & Moisture \% & $\begin{array}{l}\text { Swelling } \\
\text { index }\end{array}$ \\
\hline 1 & 6.3 & 0.56 & 3 minutes & 10 & 15.6 \\
2 & 62.6 & 0.61 & 3 minutes & 12.48 & 13.6 \\
3 & 63 & 0.58 & 4 minutes & 13.95 & 12.8 \\
4 & 63.56 & 0.57 & 5 minutes & 14 & 11.9 \\
\hline
\end{tabular}

Table 4 above is showing that the water holding capacity of the blends increases with increase in rapoko concentration. The bulk density generally lies on the same range for all the concentrations. There is a slight decrease from $30 \%$ to $40 \%$ with an increase in the $60 \%$ concentration. The swelling index decreases from $30 \%$ to $60 \%$ and thereafter it remained constant. Reconstitution time also increases with increase in rapoko concentration due to the increase in bulky density of the blends. The lower the rapoko concentration, the lower the moisture content and the reverse is true.

Sensory Evaluation Results

A total of twenty questionnaires were administered and all the twenty were returned $(100 \%)$

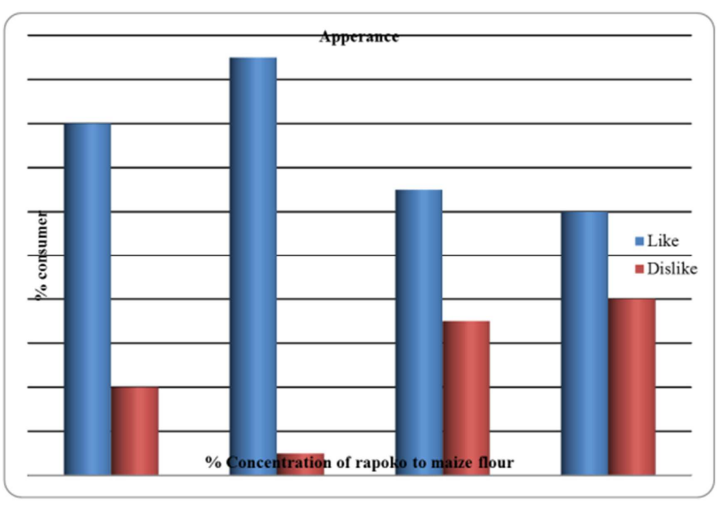

Figure 7. Appearance of the porridge as ranked by consumers.
The graph above shows the overview of consumer acceptance to the appearance of different blends of the porridge. It is shown that the appearance of all the concentration was generally acceptable to most consumers, with $30 \%$ having the highest ranks. $40 \%$ and $60 \%$ were not acceptable to some of the consumers, as shown by the higher percentages ranging from $35-40 \%$.

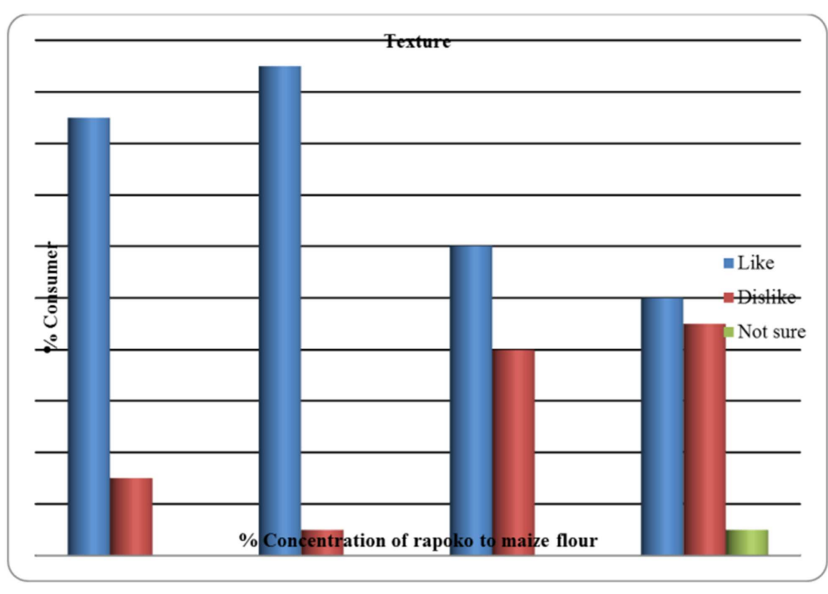

Figure 8. Consumer acceptability of the texture instant porridge blends.

In the graph above, there is a decrease in consumer acceptance for the texture of the blends as concentration of rapoko increases from $30 \%$ to $60 \%$. $0 \%$ and $30 \%$ concentration have the highest scores on like and their texture was more acceptable since there are no consumers who ranked them on dislike.

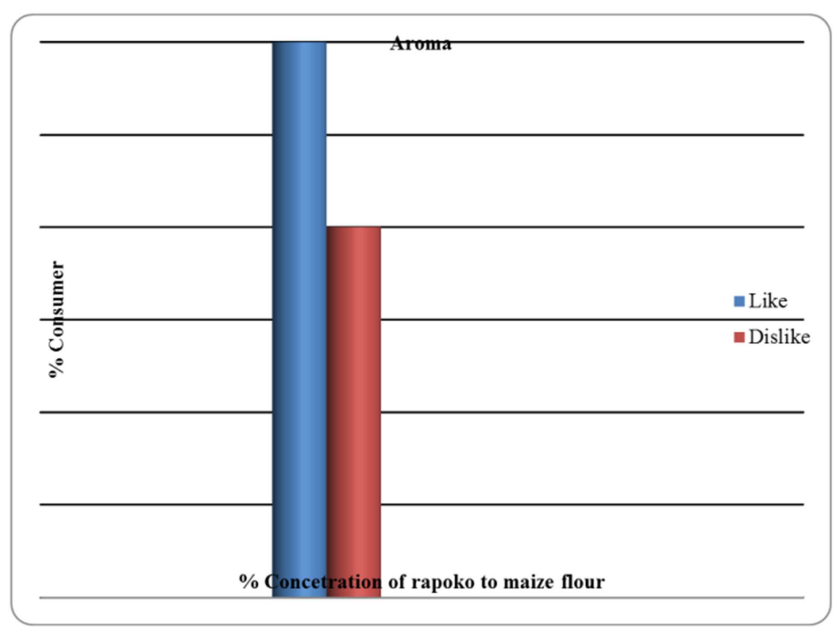

Figure 9. Aroma of the porridge as ranked by consumers.

Generally, the aroma of all the samples was acceptable to consumers as they ranged above $50 \%$ on all the samples. $30 \%$ rapoko had the highest ranking on consumer acceptance and $60 \%$ concentration has the lowest rankings meaning most of the consumers did not like the aroma of that sample. The aroma was attributed to the fermentation of the corn thus the higher the corn concentration in the porridge, the more acceptable the aroma. 


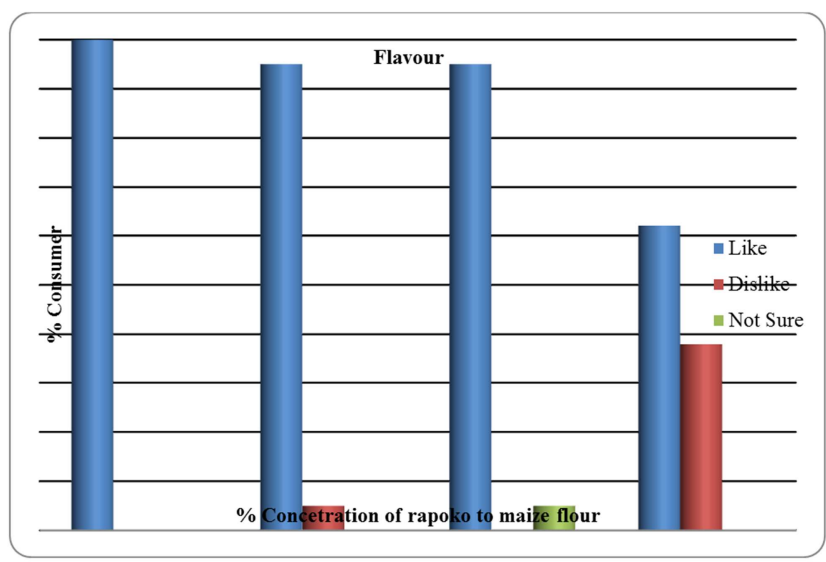

Figure 10. Consumer acceptability of the flavour of instant porridge blends.

$100 \%, 95 \%$ and $95 \%$ of the consumers liked extremely the flavour of the $0 \%, 30 \%$ and $40 \%$ concentration respectively, with about $35 \%$ and $20 \%$ of the population disliking that of $60 \%$. Generally, the flavour of all the samples was acceptable to consumers and this could be due to the addition of fermented corn which enhanced the flavour of the porridge.

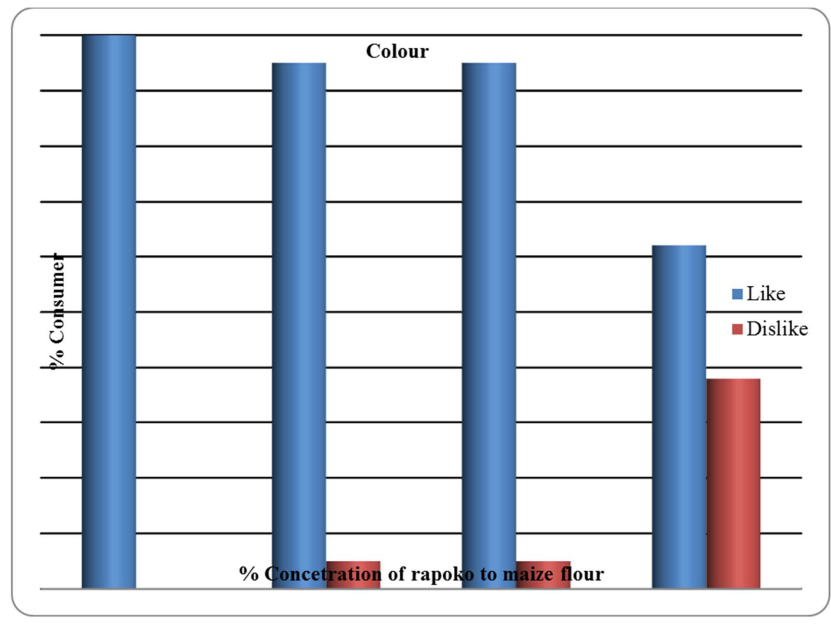

Figure 11. Consumer acceptability on colour.

$0 \%, 30 \%$ and $40 \%$ concentrations had the highest ranks for colour as compared to that of 60 . A significant number $35 \%$ did not like the colour of $60 \%$.

Consumer overall acceptability of the porridge

$30 \%$ concentration positioned on the top in relation to consumer acceptability with a percentage of $61 \%$, with $0 \%$ having the least rank $39 \%$.

Table 5. Proximate analysis results.

\begin{tabular}{|c|c|c|c|c|c|}
\hline $\begin{array}{l}\text { Parameter } \\
\mathrm{m} / \mathrm{m}\end{array}$ & $\begin{array}{l}\text { Cooked } \\
\text { Rapoko }\end{array}$ & $\begin{array}{l}\text { Fermented } \\
\text { maize }\end{array}$ & $\begin{array}{l}30 \% \\
\text { Rapoko }\end{array}$ & $\begin{array}{l}40 \% \\
\text { Rapoko }\end{array}$ & $\begin{array}{l}60 \% \\
\text { Rapoko }\end{array}$ \\
\hline Protein & 8.9 & 6.8 & 10.5 & 11.6 & 11.9 \\
\hline Crude fat & 4.8 & 4.9 & 2.4 & 4.5 & 4.6 \\
\hline Mineral ash & 0.9 & 2.8 & 2.3 & 2.8 & 2.5 \\
\hline Moisture & 11.0 & 11 & 10 & 12.5 & 13.9 \\
\hline Crude fibre & 1.9 & 2 & 5.9 & 4.9 & 4.3 \\
\hline Carbohydrates & 72.3 & 75.9 & 61.8 & 65.3 & 73.5 \\
\hline Energy & 350 & 333 & 315 & 333 & 365 \\
\hline
\end{tabular}

\section{Discussion}

The research project was focusing more on the protein, energy and carbohydrate content of the product and the effect of fermentation on the nutritional quality of the product. From the results, it is shown that there is a decrease in the nutritional content of fermented and cooked maize in relation to protein, carbohydrate and fibre. The reduction in protein content in fermented maize may be due to leaching of the nitrogen into the soaking water thus reducing the protein content (Michael n.d). Fermentation reduces the carbohydrate and fibre content of food products as the microorganisms use up the starches as a source of energy (Chelule, 2010). The increase in moisture content in fermented maize is due to the increased water solubility of the maize by processing (Jaybhaye, 2004). Fermentation is also known to increase the ash content by the reduction of the phytates (Chelule, 2010) thus the high increase in ash content in fermented maize (0.50 to 2.88).

Corn and rapoko grains are known to have a considerable amount of carbohydrate and protein and carbohydrate content of corn increased in cooked rapoko flour from $62.2 \%$ to $72.32 \%$ and in fermented corn from 72.6 to $75.9 \%$. Carbohydrate content was shown to increase with increase in the concentration of rapoko in the blend. The increase in carbohydrate content was probably due to the nutritional quality of rapoko over maize and this revealed their mutual supplementation effect (Saleh et al, 2013). The processing technologies applied on corn and rapoko grains like fermentation also have a positive outcome on the nutrient content of the product (Onyango et al, 2004). Protein content from $0 \%$ to $60 \%$ rapoko concentrations increases from 6.80 to $11.95 \%$ and this is likely to be due to the addition of rapoko flour (which has a higher protein content over corn) in the blend (Saleh et al, 2013). These results showed that the porridges were nutritious in relation to protein as they provide one third of the Recommended Dietary Allowance (RDA) from $10-12 \%$ as recommended by the World Health Organization (Mbata et al, 2007). This may be due to an increase in rapoko concentration in the blend adding to protein quality and thus leading to increased protein content as rapoko was shown to have a higher protein content when cooked 8.92 than that of fermented maize 6.80. Ikya et al, 2013 supported this by showing that supplementing fermented maize with a high protein content flour increases the overall protein content in food products. He was studying the nutritional profile and consumer acceptability of a fermented maize and full fat soy flour product (agidi) and the results showed an increase in the protein content in the blends with increase in soy flour. Protein content was 8.92; $16.55 ; 20.63$ and $20.77 \%$ in $0 ; 15 ; 20$ and $30 \%$ soy concentration respectively (Ikya et al, 2013). Fermented corn also contributed a certain percentage in the protein content of the product (Chelule, 2010). This can be the cause of the higher levels of protein in $30 \%$ and $40 \%$ rapoko concentrations where the fermented maize quantities are high. Onyango et al, 2005 observed that the protein increase 
after fermentation is accredited to the decrease in carbon ratio due to usage of carbohydrates as energy sources and producing carbon dioxide which causes the rise in nitrogen concentration in the fermented product. A study to investigate the influence of spontaneous fermentation on the nutrient composition of a fermented maize product, doklu was carried out and the fermented product was found to have appreciable nutritional composition (Assohoun et al, 2013). The protein, fatty and total soluble sugars were reduced from 8.2, 0.64 and 0.01 to $7.3,0.18$ and 0.24 respectively during 24 hours of fermentation of the doklu (Assohoun et al, 2013). The protein content was comparable to that of fermented corn flour in the research project. The decrease of fatty and soluble sugars may be due to the action of microorganisms during fermentation which tend to use them as sources of energy and this decrease can also lead to improved protein content (Chelule, 2010). The energy content of the corn and rapoko porridge increased with increase in rapoko concentration in the blend, from $0 \%(333.52)$ to $60 \%$ (365.28 kcal $/ 100 \mathrm{~g})$. The increase is attributed to the increase in protein, carbohydrate and fat content in the blends due to fermentation which is known to act on the complex form of nutrients and reduce them to simple ones, thus starch is reduced to simple sugars aiding in the improved calorie increase (Onyango et al, 2004). This high caloric value of the instant porridge blends proves that the corn and rapoko blend instant porridge would be a good source of energy.

The swelling index in flours determines the amount of free polysaccharides on addition of excess water, it reflects the macromolecular degradation of starch and higher levels indicate presence of dextrinized starch molecules (Oikonomou and Krokida, 2011). The increase in rapoko concentration in the blends led to a decrease in the physical properties of the instant porridge. From the results it is shown that the swelling index decreases from 13.6-11.9 from 0\%$60 \%$. The higher values in high corn concentration were attributed to fermentation probably due to changes in reducing sugars and starches by the action of microorganisms during fermentation. This was supported by a study by (Zeng et al, 2012) who found that the swelling power, solubility and water binding capacity of corn flours increased after fermentation from $12.54 \%, 8.42 \%$ and $45.21 \%$ to $16.26 \%$, $16.26 \%$ and $6.50 \%$ respectively. Uniform particle size is required in porridge blends so as to improve the product quality by obtaining a product with good consistency. It has great impact on appearance, viscosity, consistency and reconstitut ability of the final product. In this study, the best time for the porridge was found to be 5 minutes in hot water and this is similar to that obtained by Gunathilake and Gamlath, 2002 in their study on the development of herbal porridge mixtures. Bulk density determines the packaging of a food product, thus products with lower bulky density require less quantities in packaging thus reducing economic costs. The results showed the bulk densities of the porridge to range from 0.56 to 0.61 and the results were comparable to those of fermented popcorn flour which ranges from $0.797 \pm$ 0.040 by (Ijarotimi and Kashinro, 2011). The results obtained showed that the moisture content of the instant porridge varied from $0 \%$ to $60 \%$ rapoko concentration. The moisture content increased with increase in the concentration of rapoko in the blend because of the high moisture content in rapoko flour.

Increase in the concentration of rapoko in the blends of instant porridge has an effect on the organoleptic quality of the porridge. Sample 1 (control) was liked by most consumers as it has a better taste and flavour as compared to the other samples. This was attributed to the high concentration of fermented corn flour in the blend. Fermentation is known to improve consumer acceptability in terms of flavour, aroma, texture, taste and colour. Flavours are formed during fermentation through blending complex flavours and the existence of aromas such as diacetyl acetic acid and butyric acid (Singh et al, 2013). Sample 4 was least liked because of its poor properties, since it contain a higher concentration of rapoko and it is characterized by a rapoko flavour which is uncommon in consumers. The colour of all the samples was generally liked by the consumers, with $60 \%$ and $70 \%$ ranking the least. This was because of the rapoko brown colour and as the rapoko concentration increases, so is the brown colour becoming darker and hence consumers are not used to dark colours in relation to porridges. This was backed up by various sensory studies done in Nigeria which showed that generally, the consumers favoured sorghum and millet foods with more lighter colours than darker ones (Moussa et al, 2011). The little percentage who liked the product, it was probably because they were used to the rapoko taste and colour. The colour of a food product has an effect on the general acceptance of a food product thus increase in rapoko concentration affected the appearance of the porridge. Most consumers ranked sample 2 and 3 best because they have an appearance which is close to that of the control sample 1 . Overally, 30\% concentration was rated best because all its attributes; flavour, texture; colour are close to that of our control though it contained the lowest nutritional value as compared to the other formulations.

\section{Conclusion}

The Fermentation of corn together with the fortification of corn with rapoko flour in different concentrations proved to be feasible as there was energy, carbohydrate and protein content increase in the fermented corn and rapoko blend instant porridge with increase in rapoko concentration. However, increase in rapoko concentration led to reduction in the physical properties and sensory attributes of the fermented corn and rapoko blend instant porridge and as a result of these factors it is impractical to use all the formulations in the commercial production of the instant porridge because of the poor qualities of other formulations. The 30\% rapoko concentration was found to be the best despite the fact that it provides low energy, carbohydrate and protein content as compared the other formulations, but in relation to protein content the results showed that the $30 \%$ rapoko concentration also provide one third of the Recommended Dietary 
Allowance (RDA) for children and women which ranges from $10-12 \%$ as recommended by the World Health Organization (Mbata et al, 2007). This was also supported by the overall consumer acceptability of the $0 \%$ and $30 \%$ rapoko concentrations where the $30 \%$ had the highest rankings as compared to the unfortified fermented corn flour.

\section{References}

[1] Afoakwa, E. O., Adjonu, R. and Asomaning, J. (2010). Viscoelastic properties and pasting characteristics of fermented maize: influence of the addition of malted cereals. International Journal of Food Science and Technology 45, 380-386.

[2] Aisbitt, B., Caswell, H. and Lunn, J. (2008). Cereals- current and emerging nutritional issues. British Nutrition Foundation Nutrition Bulleting, 33, 169-185.

[3] Amagloh, F. K., Mutukumira, A. N., Brough, L., Weber, J. L, Hardacre, A and Coad, J. (2013). Carbohydrate composition, viscosity, solubility, and sensory acceptance of sweet potatoand maize-based complementary foods. Food and Nutrition Research 57: 18717.

[4] Amankwah, E. A, Barima, J., Acheampong, L. O. and Nnaji, C. O. (2009). Effect of fermentation and malting on the viscosity of maize-soya bean weaning blends. Pakistan Journal of Nutrition 8 (10): 1675-1675.

[5] Ashworth, A., and Draper, A. (n.d). The potential of traditional technologies for increasing the energy density of weaning foods: A critical review of existing knowledge with particular reference to malting and fermentation. WHO/CCD/EDP/92.4.

[6] Assohoun, M. Cntat. N, Djeni, T. N, Camara, M. K, and Brou, K. (2013). Effects of fermention on nutritional composition and Aflatoxins concentration of Doklu, a fermented maize based food. Food and Nutrition Sciences, 4, 1120-1127.

[7] Chelule, P. K., Mbongwa, H. P, Carries, S and Gqaleni, N. (2010). Lactic acid fermentation improves the quality of Amahewu, a traditional South African maize-based porridge. Food Chemistry. 122 (3):656-661.

[8] Chelule, P. K., Mokoena, M. P. and Gqaleni, N. (2010). Advantages of traditional lactic acid bacteria fermentation of food in Africa. Mendez A. (Ed.). Current Research Technology and Education Topics in Applied Microbiology and Microbial Biotechnology.

[9] Desai A. D, Kulkarni S. S, Sahoo A. K, Ranveer R. C and Dande P. B (2010). Effect of Supplementation of Malted Ragi Flour on the Nutritional and Sensorial Quality Characteristics of Cake. Advance Journal of Food Science and Technology 2(1): 67-714.

[10] Devi P. B., Vijayabharathi, R., Sathyabama, S., Malleshi, N. and Priyadarisini V. B. (2001). Health benefits of finger millet (Eleusine coracana L) polyphenols and dietary fibre: a review. J Food Sci Technol. DOI 10.1007/s13197-011-0584-9.

[11] Enpeng, L., Sushil, D and Jovin, H. (2014). Effects of milling on starch structures and flour/starch properties. Starch/Starke. 15-27.

[12] Enwere, N. J. (2005)." Effect of ripe fruit pulp on the sensory and nutritive quality of ready-to-eat breakfast cereal produced from maize and soybean flours and cassava starch blends", International Journal of Food Science and Nutrition, 2.1.

[13] Filli, K. B., Nkama, I., Jideani, V. A., and Abubakar, U. M. (2013). Application response surface methodology for the evaluation of proximate composition and functionality of millet-soy bean fura extrudates. Wudpecker Journal of Food Technology. 1(5): 074-092.

[14] Food and Nutrition Council [FNC] and Ministry of Health and Child Welfare [MoHCW], (2010). Nutrition Survey Report.

[15] Hubner, F. and Arendt, E. (2013). Germination of cereal grains as a way to improve the nutritional value: A review. Critical reviews in Food Science and Nutrition, 53:853-861

[16] Ijarotimi, S. O. and Keshniro, O. O. (2011). Determination of Amino Acid, fatty acid, mineral, Functional and Choking Properties of Germinated and Fermented Popcorn (Zea mays everta) Flour. European Journal of Food Research and Review. 1(2): 102-122.

[17] Ikya, J. K., Gernah, D. L. and Sengev, I. A. (2013). Proximate Composition, nutritive and sensory properties of fermented maize, and full fat soy flour blends for agidi production. 7(12): 446-450.

[18] Ingbian, E. K. and Akpapunam, M. A. (2005). Appraisal of Traditional technologies in the Processing and utilization of Mumu; A cereal based local food product. African Journal of Food and Nutrition Sciences, 5:2.

[19] Irén Léder, (2004), Sorghum and Millets, in Cultivated Plants, Primarily as Food Sources, [Ed. György Füleky], in Encyclopedia of Life Support Systems (EOLSS), Developed under the Auspices of the UNESCO, Eloss Publishers, Oxford, UK.

[20] Mbaeyi-Nwaoha, I. E. and Onweluzo, J. C. (2013). Properties of Sorghum (S. bicolor L.)- Pigeon pea (Cajanus cajan) Flour Blends and Storage Stability of a Flaked breakfast Formulated from Blends. Pakistan Journal of Nutrition 12(4): 382-397.

[21] Mbata, T. I, Ikenebomeh, M. J. and Ahonkhai, I. (2007). Nutritional status of maize fermented meal by fortification with bambara-nut. African Journal of Food and Agriculture Nutrition and Development. 7:2.

[22] McKevith, B. (2004). Nutritional Aspects of cereals. British Nutrition Foundation, London, UK, 29, 11-142.

[23] Michael, H. W. (n.d). Influence of processing on anti-nutrients and production of some value added finger millet based products. Thesis. PhD. Addis Ababa Institute of Technology.

[24] Mittal, M. (2002). Development of finger millet and barnyard millet based convenience mixes for food products and their evaluation for nutritional quality, storage stability and acceptability. Thesis. PhD. G. B. Pant Univ. of Agric and Technol, Pantnagr. P.260.

[25] Moussa, M., Qin., X., Chen., L., Campanella, O. H. and Hamaker, B. R. (2011). High quality instant sorghum porridge flours for the West Africa market using continuous processor cooking. International Journal of Food Science and Technology, 46, 2344-2350

[26] Mugula, J. K. and Lyimo, M. (2000). Evaluation of the nutritional quality and acceptability of sorghum-based Tempe as potential weaning foods in Tanzania. International Journal of Food Science and Nutrition. 51:269-277. 
[27] Neulicht, R. and Shular, J., (1995). Cereal Breakfast Food. Midwest research institute. Emission Factor Documentation for AP-42, Section 9.9.2. Final report U.S.A.

[28] Onyango C., Noetzold, H., Bley, T. and Henle, T. (2005). Proximate composition and digestibility of fermented and extruded uji from maize-finger millet blend. LWT- Food Science and Technology, 37:8, 827-832.

[29] Onyango, C. (2004)."Proximate composition and digestibility of fermented and extruded uji from maize-finger millet blend", LWT - Food Science and Technology, 12.

[30] Qing-Bo, Ainsworth P, Tuker, G. and Mason, H. (2005). The effect of extrusion variables on some functional properties of extruded millet-soybean for the manufacture of "fura": A Nigerian traditional food. African Journal of Food Science. 4(6):342-352

[31] Roos N, Sorensen J. C., Sorensen H., Rasmussen S. K., Briend A., Yang Z. and Huffman, S. L. (2012). Screening of antinutritional compounds in complementary foods and food aid products for infants and young children. Maternal and Child Nutrition. Blackwell Publishing, 9: 47-71.

[32] Saleh, Ahmed S. M., Qing Zhang, Jing Chen, and Qun Shen. (2013). "Millet Grains: Nutritional Quality, Processing, and Potential Health Benefits: Millet grains", Comprehensive Reviews in Food Science and Food Safety.
[33] Sanni, A. I. and Adesulu, A. T. (2013). Microbiological and physic-chemical changes during fermentation of maize for masa production. African Journal of Microbiology Research. 7(34):4355-4362.

[34] Singh, A. K, Rehal, J., Kaur, A. and Jyot, G. (2013). Enhancement of attributes of Cereals by Germination and Fermentation: A Review, Critical reviews in food science and nutrition, DOI:10.1080/10408398.2012.706661.

[35] Singh, B. P, Jha, A, Sharma, N. and Rasane, P. (2013). Optimization of a process and development of a shelf life prediction model for instant multigrain Dalia mix. Journal of food processing engineering. ISSN 1745-4530.

[36] Steinkraus, K. H. (2002). Fermentations in World Food Processing. Comprehensive Reviews in Food Science and Food Safety. Vol 1.

[37] Verna, V. and Patel, S. (2013). Value added products from nutri-cereals: Finger millet (Eleusine coracana). Emir. J. Food Agric, 25(3): 169-176.

[38] Zeng, J., Gao, H., Li, G. and Zhao, X. (2012). Characteristics of corn flour fermented by some Lactobacillus species. China Academic Journal Electronic Publishing House.

[39] Zimbabwe National Nutrition Survey [ZNNS], (2010). Rapid Nutrition Survey Report. 